\title{
Peripheral clocks tick independently of their master
}

\author{
Anna-Marie Finger and Achim Kramer \\ Charité-Universitätsmedizin Berlin, corporate member of Freie Universität Berlin, Humboldt-Universität zu Berlin, \\ and Berlin Institute of Health, Laboratory of Chronobiology, 10117 Berlin, Germany
}

\begin{abstract}
The circadian system of mammals is hierarchically organized. The suprachiasmatic nucleus (SCN) in the hypothalamus is considered the master circadian clock adapting to environmental light-dark cycles and synchronizing subsidiary oscillators in peripheral organs. While being an attractive concept, this has never been convincingly shown in vivo. New findings by Sinturel and colleagues (pp. 329-334) in this issue of Genes \& Development now show the requirement of the SCN for temporal orchestration of the periphery in living animals. Surprisingly, this study also found that even in the absence of SCN or extra-SCN clocks, peripheral clocks remain rhythmic, indicating previously controversial circadian oscillator coupling within peripheral tissues.
\end{abstract}

Circadian clocks are endogenous timing systems that evolved in almost all organisms to anticipate and adapt to 24-h cycles in the environment. Since the discovery of the SCN as master clock in 1972 (Stephan and Zucker 1972) and peripheral clocks in 1998 (Balsalobre et al. 1998), the question of whether and how the SCN synchronizes peripheral clocks is a matter of intense research. Multiple pathways have been proposed, including bloodborne signals as well as feeding-fasting and body temperature cycles (Fig. 1; for a review, see Finger et al. 2020). A limitation of all of those studies was that peripheral clocks, in contrast to the SCN clock, for which locomotor activity rhythms are an accepted readout, could not be observed in living animals. For the same reason, it also remained elusive whether peripheral rhythms persist in vivo in the absence of an SCN or other rhythmic inputs. Circadian rhythms from peripheral (but not SCN) tissue explants damp rapidly in vitro, which has been interpreted as dephasing of single oscillator cells due to (1) their variable intrinsic periods and (2) a lack of intercellular coupling (for a review, see Finger et al. 2020). However, several studies provided evidence for SCN-independent rhythmicity of peripheral clocks (Tahara et al. 2012; Saini et al. 2013).

The study by Sinturel et al. (2021) now reinforces the concept of autonomous peripheral oscillators, which

Corresponding author: achim.kramer@charite.de Article is online at http://www.genesdev.org/cgi/doi/10.1101/gad.348305. 121. depend on the SCN only to establish synchrony among but not within peripheral body clocks. In mammals and likely other organisms, synchronization between cell-autonomous circadian oscillators within tissue networks is achieved by intercellular coupling (Fig. 1). While it is well established that neuronal oscillators within the SCN strongly couple via the exchange of neurotransmitters or gap junctions (for a review, see Finger et al. 2020), it is controversial whether intercellular oscillator coupling occurs within peripheral tissues. Conceptually, intercellular coupling accounts for the coherence and robustness of circadian ensemble rhythms; i.e. it enhances tissue amplitudes due to resonance and prevents damping due to synchronization between cellular oscillators. In addition, coupling determines entrainment range and susceptibility to incoming Zeitgeber signals by making oscillator ensembles more rigid or robust (Abraham et al. 2010; Schmal et al. 2018). Thus, from a physiological perspective, by rendering circadian rhythms more robust, intercellular coupling is crucial for maintaining normal entrainment behavior of the body clocks and thereby the correct phasing and amplitude of circadian tissue functions. Since peripheral clocks are exposed to a multitude of clock-modulating signals emanating from the noisy environment or other body clocks, daily synchronization by the SCN master oscillator might not be sufficient to ensure precise peripheral rhythm dynamics.

Indeed, Sinturel et al. (2021) show that peripheral circadian rhythms persist in vivo even without rhythmic input from the SCN or extra-SCN body clocks. To this end, they exploited their RT-Biolumicorder technology (Saini et al. 2013), a state of the art method to monitor peripheral circadian bioluminescence rhythms from clock gene reporters in real time in freely moving mice. Specifically, the liver clock oscillates robustly and with similar amplitudes and periods in both SCN-proficient and -deficient animals maintained in constant conditions. Importantly, liver circadian rhythms also persist, although with reduced amplitude, in hepatocyte clock-only mice; i.e. in mice where

(C) 2021 Finger and Kramer This article is distributed exclusively by Cold Spring Harbor Laboratory Press for the first six months after the full-issue publication date (see http://genesdev.cshlp.org/site/misc/terms.xhtml). After six months, it is available under a Creative Commons License (Attribution-NonCommercial 4.0 International), as described at http://creativecommons.org/licenses/by-nc/4.0/. 


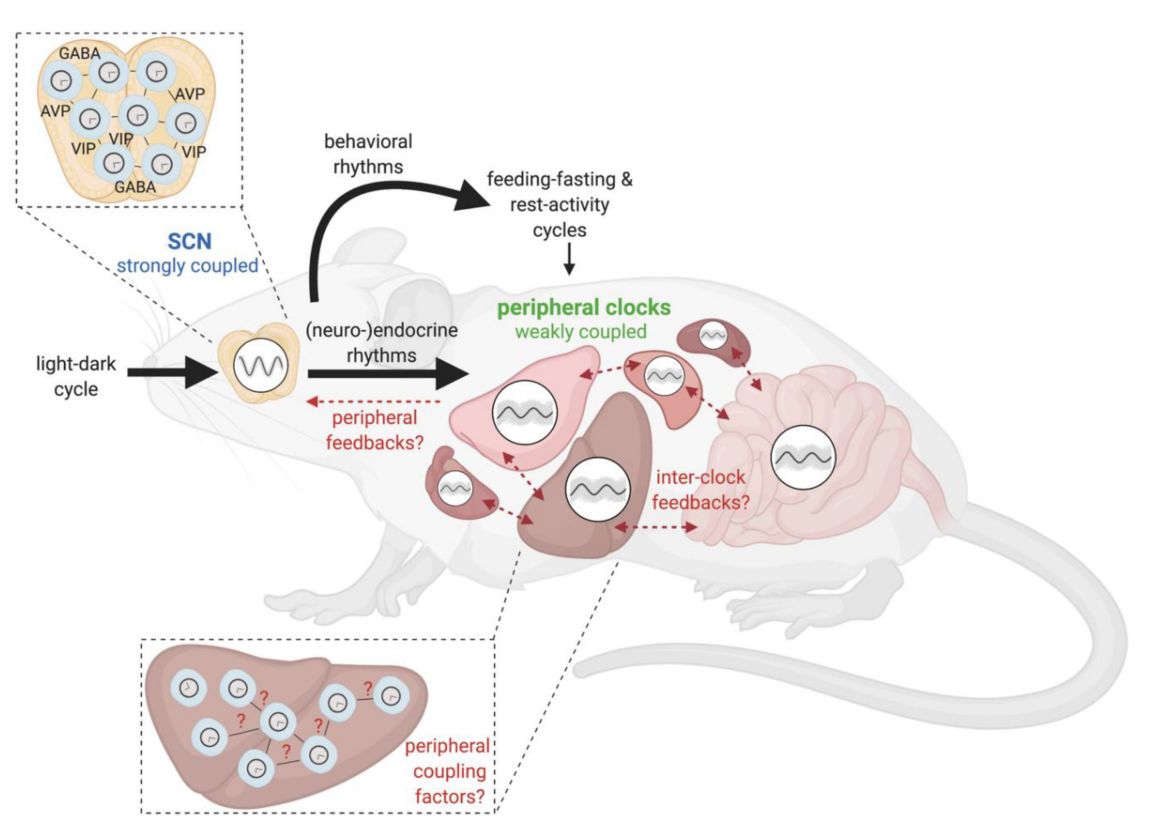

Figure 1. Organization of the mammalian circadian system. The circadian system in mammals consists of multiple body clocks. The suprachiasmatic nucleus (SCN) in the hypothalamus constitutes a highly robust oscillator network due to intercellular neurotransmitter coupling. (GABA) $\gamma$-Aminobutyric acid, (AVP) arginine vasopressin, (VIP) vasoactive intestinal polypeptide. It receives photic entrainment signals from the environment, which are transmitted via multiple behavioral and (neuro-lendocrine pathways, to peripheral body clocks in order to align them with the external light-dark cycle, as well as with each other. Peripheral oscillators constitute weakly coupled, yet autonomous, body clocks that drive rhythmic tissue functions. Whether peripheral clocks exchange mutual or peripheral-tocentral feedback signals, as well as which factors mediate intercellular coupling within peripheral tissues, is currently unknown. functional molecular clocks are exclusively present in hepatocytes. These results are inconsistent with findings by Koronowski et al. (2019), who did not observe rhythmic gene expression in hepatocyte clock-only mice kept in constant conditions. However, as this study collected tissue samples from different animals per time point, lowamplitude peripheral rhythms have likely been missed due to dephasing between animals rather than between hepatocyte oscillators.

In contrast to traditional concepts of the mammalian circadian system, these new findings indicate that peripheral clocks are not mere servile oscillators driven by the SCN. They are able to maintain coherent circadian rhythms in vivo independent of the SCN or extra-SCN inputs due to coupling among oscillator cells. Nevertheless, we cannot abandon the hierarchical concept altogether. Sinturel et al. (2021) also show that in SCN-lesioned animals housed in constant conditions, the amplitude of whole-body bioluminescence rhythms is strongly reduced. This demonstrates that the SCN master clock is important for maintaining synchrony among non-SCN body clocks.

What are the open questions? Because of the many redundant signals contributing to systemic circadian rhythm generation, it has been and still will be a challenge to identify the molecular pathways of how the SCN modulates the peripheral clock (Fig. 1). In addition, Sinturel et al. (2021) also propose that (unknown) signals from extra-SCN clocks are required for phase coherence of peripheral clock rhythms. Indeed, a recent study by Guan et al. (2020) provided evidence for intercellular communication between different cell types in controlling rhythmic liver gene expression. In this context, it will be interesting to decipher which of the many rhythmic signals to which a peripheral clock is exposed (1) directly drives rhythmic gene expression without the need of a clock; (2) synchro- nizes the cell-autonomous peripheral oscillator cells, thereby indirectly controlling rhythmic gene expression; or (3) helps to phase-align peripheral oscillator cells, thereby expanding gene expression amplitudes. Finally yet importantly, the mechanism of intercellular coupling among hepatocytes (and other peripheral tissue cells) remains entirely elusive. Is there coupling in all peripheral tissues and, if yes, is there a universal coupling factor? The study by Sinturel et al. (2021) liberates, at least in part, peripheral subsidiary oscillators from the dependence of the master in the SCN and opens new research avenues for identifying and characterizing clock-to-clock communication routes.

\section{Acknowledgments}

We thank Joachim Herz Stiftung (to A.F.) and Deutsche Forschungsgemeinschaft grants TRR186 (project no. 278001972) and KR1989/12-1 (to A.K.).

\section{References}

Abraham U, Granada AE, Westermark PO, Heine M, Kramer A, Herzel H. 2010. Coupling governs entrainment range of circadian clocks. Mol Syst Biol 6: 438. doi:10.1038/msb .2010 .92

Balsalobre A, Damiola F, Schibler U. 1998. A serum shock induces circadian gene expression in mammalian tissue culture cells. Cell 93: 929-937. doi:10.1016/S0092-8674|00|81199-X

Finger AM, Dibner C, Kramer A. 2020. Coupled network of the circadian clocks: a driving force of rhythmic physiology. FEBS Lett 594: 2734-2769. doi:10.1002/1873-3468.13898

Guan D, Xiong Y, Trinh TM, Xiao Y, Hu W, Jiang C, Dierickx P, Jang C, Rabinowitz JD, Lazar MA. 2020. The hepatocyte clock and feeding control chronophysiology of multiple liver 
cell types. Science 369: 1388-1394. doi:10.1126/science .aba8984

Koronowski KB, Kinouchi K, Welz PS, Smith JG, Zinna VM, Shi J, Samad M, Chen S, Magnan CN, Kinchen JM, et al. 2019. Defining the independence of the liver circadian clock. Cell 177: 1448-1462.e14. doi:10.1016/j.cell.2019.04.025

Saini C, Liani A, Curie T, Gos P, Kreppel F, Emmenegger Y, Bonacina L, Wolf JP, Poget YA, Franken P, et al. 2013. Real-time recording of circadian liver gene expression in freely moving mice reveals the phase-setting behavior of hepatocyte clocks. Genes Dev 27: 1526-1536. doi:10.1101/gad.221374.113

Schmal C, Herzog ED, Herzel H. 2018. Measuring relative coupling strength in circadian systems. J Biol Rhythms 33: 8498. doi:10.1177/0748730417740467
Sinturel F, Gos P, Petrenko V, Hagedorn C, Kreppel F, Storch K-F, Knutti D, Liani A, Weitz CJ, Emmenegger Y, et al. 2021. Circadian hepatocyte clocks keep synchrony in the absence of a master pacemaker in the suprachiasmatic nucleus or other extrahepatic clocks. Genes Dev (this issue). doi:10.1101/gad .346460 .120

Stephan FK, Zucker I. 1972. Circadian rhythms in drinking behavior and locomotor activity of rats are eliminated by hypothalamic lesions. Proc Natl Acad Sci 69: 1583-1586. doi:10.1073/pnas.69.6.1583

Tahara Y, Kuroda H, Saito K, Nakajima Y, Kubo Y, Ohnishi N, Seo Y, Otsuka M, Fuse Y, Ohura Y, et al. 2012. In vivo monitoring of peripheral circadian clocks in the mouse. Curr Biol 22: 1029-1034. doi:10.1016/j.cub.2012.04.009 


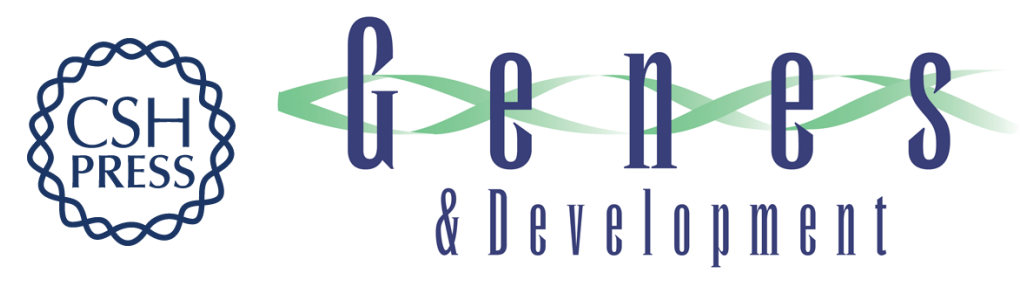

\section{Peripheral clocks tick independently of their master}

Anna-Marie Finger and Achim Kramer

Genes Dev. 2021, 35:

Access the most recent version at doi:10.1101/gad.348305.121

Related Content Circadian hepatocyte clocks keep synchrony in the absence of a master pacemaker in the suprachiasmatic nucleus or other extrahepatic clocks

Flore Sinturel, Pascal Gos, Volodymyr Petrenko, et al.

Genes Dev. March , 2021 35: 329-334

References This article cites 10 articles, 5 of which can be accessed free at:

http://genesdev.cshlp.org/content/35/5-6/304.full.html\#ref-list-1

Articles cited in:

http://genesdev.cshlp.org/content/35/5-6/304.full.html\#related-urls

Creative This article is distributed exclusively by Cold Spring Harbor Laboratory Press for the first Commons

License

six months after the full-issue publication date (see

http://genesdev.cshlp.org/site/misc/terms.xhtml). After six months, it is available under a Creative Commons License (Attribution-NonCommercial 4.0 International), as described at http://creativecommons.org/licenses/by-nc/4.0/.

Email Alerting Receive free email alerts when new articles cite this article - sign up in the box at the top Service right corner of the article or click here.

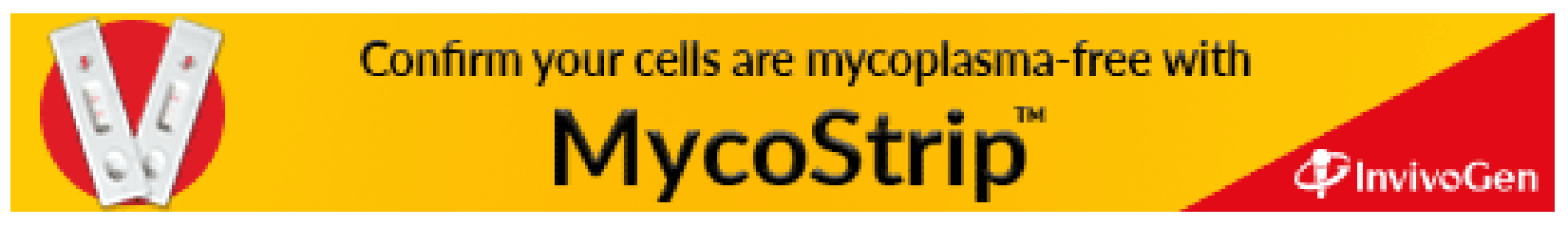

